\title{
An Examination of the Performance Anxiety Levels of Undergraduate Music Teaching Students in the Instrument Exams According to Various Variables (Case of Tokat Province)
}

\author{
Mehmet Serkan Umuzdaş ${ }^{1}$, Hatice Tök ${ }^{2}$ \& Serpil Umuzdaş ${ }^{3}$ \\ ${ }^{1}$ Assoc. Prof, Tokat Gaziosmanpasa University, State Conservatory, Tokat, Turkey \\ ${ }^{2}$ MS Student, Gaziosmanpasa University, State Conservatory, Tokat, Turkey \\ ${ }^{3}$ Assoc. Prof, Tokat Gaziosmanpasa University, State Conservatory, Tokat, Turkey \\ Correspondence: Mehmet Serkan Umuzdaş, Assoc. Prof, Tokat Gaziosmanpasa University, State Conservatory, \\ Tokat, Turkey. E-mail: sumuzdas@yahoo.com
}

Received: July 10, 2019

doi:10.5430/ijhe.v8n4p221
Accepted: July 26, 2019

Online Published: July 27, 2019

URL: https://doi.org/10.5430/ijhe.v8n4p221

\begin{abstract}
Quantitative descriptive method was used in order to examine the state-trait and total anxiety levels of the students in the Undergraduate Music Teaching Program by gender, instrument difference, school year and academic achievement scores of students. The study has been conducted in the fall semester of 2018-2019 academic year in Turkey with Tokat University Faculty of Education, Fine Arts Education Department Music Education Program students $(\mathrm{n}=77)$. For data collection, "The State-Trait Anxiety Inventory" developed by Spielberg et al. (1964) and adopted to Turkish by Öner and Le Compte (1983). The trait anxiety inventory was applied in a time period when the students were away from exam stress. The state anxiety inventory, on the other hand, was conducted just before the final exams. According to the results of the study, when the state-trait and total anxiety of the students receiving musical instrument education in Music Teacher Education Program is examined, it was found that there is a significant difference between trait and state anxiety, that female students' trait and total anxiety levels are higher, and the male students' state anxiety is higher; when it is considered in terms of instrument differences, it was seen that students playing stringed instruments have higher anxiety than those who play bow and wind instruments, A significant difference was found in terms of academic achievement scores in undergraduate freshman and senior students who have higher anxiety .
\end{abstract}

Keywords: instrument exam, anxiety, student, performance anxiety, music education

\section{Introduction}

Anxiety is a phenomenon that was scientifically addressed by Freud for the first time in the 19th century. According to Morgan (1991), although the studies before Freud examined anxiety and fear as a whole, the differences between the concepts of anxiety and fear came to the fore over time, and fear was defined as the individual's response to the external threats and dangers. Anxiety, on the other hand, is the reaction of the individual against internal threats and dangers (Ünal Karagüven, 1999: 203). While fear usually manifests itself in a specific moment, anxiety involves our concerns about future. In this case, anxiety is usually related to events that have yet to occur. The source of anxiety is mostly unclear. Unlike fear, there is no apparent danger situation in the life of the anxious person. When fear and anxiety are compared, it is possible to argue that anxiety is a feeling that is more abstract, difficult to define and that emerges in a longer-term. However, it is also known that there are multiple types of anxiety.

Anxiety is regarded as one of the basic emotions of the individual. It is the situation in which an individual feels distress about the odds of a bad event to occur. This feeling can be of different intensity up to the extent of panic. In the event of anxiety, physiological symptoms such as increased blood pressure, tension in the muscles, dry mouth, sweating of the hands and feet may be observed. This type of anxiety caused by dangerous situations often creates the emotion that can happen to each individual and is temporarily connected to a certain situation. This type of anxiety is defined as 'state anxiety' (Öner and Le Compte 1985).

It may also be the case that an individual is constantly living in distress and is often unhappy. Trait anxiety is a type of anxiety that originates from within and is not directly associated with external threats. In this case, the individual 
perceives as if his/her self is threatened or interprets the situations surrounding him/her as stressful (Öner and Le compte, 1985).

It is usually considered that the fear and uneasiness caused by dangerous situations, are normal and temporary situations to live through by the individual. Trait anxiety, which may be indirectly related to the situation of the individual, can also determine personality characteristics. Personality characteristics can be influenced by an individual's tendency toward anxiety. An anxious individual can perceive the situations $\mathrm{s} / \mathrm{he}$ is in as stressful. The trait anxiety is the feeling of unhappiness that arises when the individual perceives ordinary situations as threatening his/her self (Öner and Le Compte, 1985). Individuals with high levels of trait anxiety can easily become upset and get into negative thoughts. These individuals experience state anxiety more intensively and more frequently than others. As seen in the interaction between trait and state anxiety, a state of anxiety which can be defined as Music Performance Anxiety has emerged in musicians due to state anxiety.

Musical performance is recognized as an important part of the music education process. Musical performance can therefore be seen as a result / output of all studies. The performance success of each student studying and receiving music education is therefore evaluated through a concert or exam. The concept of performance, which is considered to be the product produced by a music student as a result of all those tiresome and demanding practices, can lead to the experience of positive or negative feelings depending on this process. Thus, a performance may involve a multivariate structure. The power of the performance is also closely related to the appropriate and balanced management of these variables (Aydın and İşgörür, 2017).

Cox and Kenardy (1993) describe performance anxiety as the state of anxiety associated with the fear of an individual's inability to control his or her motor skills and making mistakes in front of other people. Salmon (1999), on the other hand, names performance anxiety as music performance anxiety and defines it as a state of concern about whether the performance of the individual would be sufficient before the audience, regardless of their musical talent (Fehm and Schmidt, 2006). It can be argued that while concern creates a moderate stress on the individual, anxiety causes more serious emotional stress, and while concern does not affect our professional and personal skills, anxiety does affect those.

The primary situations that raise music performance anxiety is the students' individual instrument performance (Dalkıran et al., 2014). Particularly, the students who are in front of a commission in the final exams may panic and demonstrate mental, physical, emotional and reactive symptoms triggered by anxiety for fear of being watched by others, making mistake or being disliked while performing, since they think that they will perform their individual instrument performance in a psychomotor way. This may prevent them from achieving in their exams and performing as they wish. The same can happen when performing at the stage. Although there is no fear of being graded here, students who have the fear of making mistakes, being disliked or see unexpectedly excessive number of audiences may have more anxiety about future and fail to exhibit the performance as they wish. On a par with this, it can also be observed that students who do not have enough control of themselves or their instrument may have more anxiety.

Cognitive, behavioral, and psychomotor characteristics of anxiety and music performance anxiety are frequently mentioned in the literature. Some researchers consider it the response of the autonomic nervous system as a physiological process. Physical symptoms such as increased heart rhythm, rapid breathing, sweating, frequent urination etc. are enumerated (Zinn, 2000, Kenny, 2006). Again, situations such as reluctance to perform the duty, failure to add rendition power and musical expression as a behavioral reaction, failure to add musical expressions when trying to avoid of technical mistakes, and failure to control the fingers are mentioned about (Fehm and Schmidt, 2006). Performers cognitive anxiety levels may effects the actions success if threat perception occurs. Even the cognitive dimension of anxiety is frequently emphasized in the literature (Salmon and Meyer, 1992; Kenny, 2006). It can also be argued that musical performance anxiety is the focal point of unwanted reactions, emotional state and negative experiences as well as physiological changes that are the consequences of these (Aydın and İşgörür, 2017).

\subsection{Objective}

The Undergraduate Music Teaching Program is to educate the students who become successful in the special talent entrance examination and at the end, bring up music teachers who hold the qualifications accordant with the universal norms by providing science-based education system. Moreover, the objective of Music Teacher Education Program is to bring up music teachers through a system based on participation and application. The aim of this study is to determine whether the state-trait anxiety of the students who are getting instrument education at the Undergraduate Music Teaching Program vary according to various variables. The sub-problems identified within the scope of this objective are as follows. 
1. Is there a significant difference between trait and state anxiety of undergraduate music teaching students?

2.Is the trait-state and total anxiety of undergraduate music teaching students differ by gender?

3. Is the trait-state and total anxiety of undergraduate music teaching students differ by the instrument they play?

4. Is the trait-state and total anxiety of undergraduate music teaching students differ by their school year?

5. Is the state anxiety of undergraduate music teaching students related to their academic achievement scores?

\subsection{Significance}

This study examines whether there is a significant difference between state-trait anxiety levels of Undergraduate Music Teaching Program students, who get instrument education, by their gender, school year, and the instrument they play; and whether their academic achievement scores have any impact on their trait-state anxiety. The failure on either the exams or concerts performed by the music education students may affect them negatively. With this study, various causes of anxiety experienced by undergraduate students studying at music teaching departments will be identified. Recognizing this state of anxiety will help the students at cognitive, emotional and psychomotor domains. It is important to understand whether the state-trait anxiety of Music Teaching Undergraduate Program students is differentiated according to various variables with the dimensions discussed.

\section{Methodology}

In this study where the quantitative data obtained from the students of the Music Education Undergraduate Program were processed, a descriptive survey model was administered in order to determine the state-trait anxiety levels (Karasar, 2005).

\subsection{Study Group}

The study group of this study is composed of undergraduate students $(n=77)$ studying musical instrument education at the Department of Music Education under Faculty of Education in Gaziosmanpaşa University, Tokat, as of 2018-2019 fall semester. $36.19 \%$ of the participants are female and $23.1 \%$ are male. Instrument distribution is $17.71 \%$ violin, $9.24 \%$ viola, $4.62 \%$ cello, $15.48 \%$ flute, $6.93 \%$ guitar, $6.88 \%$ baglama, and $0.86 \%$ oud.

\subsection{Data Collection Tools}

A scale was used to determine the state and trait anxiety levels of the students at the Department of Music Teaching. In order to determine the state-traitanxiety levels of the students, the "State-Trait Anxiety Inventory" developed by Spielberg et al. (1964) was used. The state anxiety scale provides information about instant emotions whereas the trait anxiety scale measures emotions related to a wide process. The State-Trait Anxiety Inventory is a 20-item and 4-point Likert scale.

\subsection{Data Analysis}

In order to determine state-trait anxiety and instrument exam performance anxiety levels of undergraduate music teaching students in terms of the variables determined in the study, "Smirnov" analysis was used for total anxiety scores," Anova" for the difference between state-traitand total anxiety levels by the instrument difference, school year and academic achievement variables and "ttest" for the difference in the same anxiety scores by gender. Normality assumption is met. Therefore, parametric tests used.

\section{Findings}

The findings obtained in line with the research purposes of the study are presented. The average scores of state and trait anxiety levels of undergraduate music teaching students are given in Table 1.

Table 1. Difference Between State and Trait Anxiety

\begin{tabular}{lllllll}
\hline Variables & $\boldsymbol{n}$ & Mean & $\boldsymbol{S ~ D}$ & $\boldsymbol{t}$ & $\boldsymbol{d}$ & $\boldsymbol{p}$ \\
\hline $\begin{array}{l}\text { State-Trait } \\
\text { Anxiety }\end{array}$ & 77 & 5.16883 & 7.40271 & 6.127 & 76 & .000 \\
\hline
\end{tabular}

Table 1 shows a significant difference between state and trait anxiety. The mean scores of state-trait and total anxiety of undergraduate music teaching students by gender are given in Table 2 . 
Table 2. T-Test Results of State-Trait Total Anxiety Scores by Gender

\begin{tabular}{|c|c|c|c|c|c|c|}
\hline Variables & $n$ & Mean & $S D$ & $t$ & $d f$ & $p$ \\
\hline \multicolumn{7}{|c|}{ State-Trait Anxiety } \\
\hline Female & 47 & 40.2766 & 5.58998 & -1.960 & 75 & .884 \\
\hline Male & 30 & 42.8000 & 5.37812 & & & \\
\hline \multicolumn{7}{|c|}{ Trait Anxiety } \\
\hline Female & 47 & 47.7447 & 4.71569 & 2.825 & 75 & .269 \\
\hline Male & 30 & 44.3667 & 5.69624 & & & \\
\hline \multicolumn{7}{|c|}{ Total Anxiety } \\
\hline Female & 47 & 88.021 & 7.7837 & 3.450 & 75 & .621 \\
\hline Male & 30 & 87.1667 & 8.64265 & & & \\
\hline
\end{tabular}

The results of the t-test on the state-trait and total anxiety levels of students by gender, anxiety levels of females and males were found to be different from each other. Trait anxiety $\left(\mathrm{t}_{0.05: 75}=2,825\right)$ levels of female students $(\mathrm{X}=$ 47.7447) is higher than that of male students $(\overline{\mathrm{x}}=44.3667)$. State anxiety $\left(\mathrm{t}_{0.05: 75}=-1,960\right)$ level of female students $(\overline{\mathrm{x}}=40.2766)$ is lower than that of male students $(\overline{\mathrm{x}}=42.8000)$. Total anxiety $\left(\mathrm{t}_{0.05: 75}=.450\right.$ level of female students $(\overline{\mathrm{x}}=88.021)$ is higher than that of male students $(\overline{\mathrm{x}}=87.1667)$.

The mean scores of state-traits and total anxiety levels of undergraduate music teaching students by instruments are given in Table 3.

Table 3a. Descriptive Statistics of State-Trait and Total Anxiety Scores by Instrument

\begin{tabular}{|c|c|c|c|}
\hline Variables & $n$ & Mean & $S D$ \\
\hline \multicolumn{4}{|c|}{ State Anxiety } \\
\hline Violin & 23 & 39.86 & 4.722 \\
\hline Viola & 12 & 41.25 & 5.986 \\
\hline Cello & 6 & 37.00 & 3.577 \\
\hline Flute & 18 & 40.83 & 3.944 \\
\hline Guitar & 9 & 45.11 & 7.540 \\
\hline Baglama & 8 & 43.87 & 6.379 \\
\hline Oud & 1 & 51.00 & \\
\hline Total & 77 & 41.25 & 5.611 \\
\hline \multicolumn{4}{|c|}{ Trait Anxiety } \\
\hline Violin & 23 & 47.73 & 4.614 \\
\hline Viola & 12 & 48.58 & 3.396 \\
\hline Cello & 6 & 45.33 & 4.633 \\
\hline Flute & 18 & 45.33 & 5.520 \\
\hline Guitar & 9 & 43.33 & 5.024 \\
\hline Baglama & 8 & 46.75 & 8.614 \\
\hline Oud & 1 & 42.00 & \\
\hline Total & 77 & 46.42 & 5.346 \\
\hline \multicolumn{4}{|c|}{ Total Anxiety } \\
\hline Violin & 23 & 87.60 & 7.396 \\
\hline Viola & 12 & 89.83 & 6.520 \\
\hline Cello & 6 & 82.33 & 5.537 \\
\hline Flute & 18 & 86.16 & 6.519 \\
\hline Guitar & 9 & 88.44 & 10.560 \\
\hline Baglama & 8 & 90.62 & 12.850 \\
\hline Oud & 1 & 93.00 . & \\
\hline Total & 77 & 87.68 & 8.083 \\
\hline
\end{tabular}


Table 3b. Anova Results of State-Trait and Total Anxiety Scores by Instrument

\begin{tabular}{lccccc}
\hline Variables & $\boldsymbol{S S}$ & $\boldsymbol{S d}$ & $\boldsymbol{M S}$ & $\boldsymbol{F}$ & $\boldsymbol{p}$ \\
State Anxiety & & & & & \\
Between groups & 439.683 & 6 & 73.280 & 2.626 & .024 \\
Within groups & 1953.123 & 70 & 27.902 & & \\
Total & 2392.805 & 76 & & & \\
Trait Anxiety & & & & & .233 \\
Between groups & 230.672 & 6 & 38.445 & 1.386 & \\
Within groups & 1942.185 & 70 & 27.745 & & .470 \\
Total & 2172.857 & 76 & & & \\
Total Anxiety & & & & & \\
Between groups & 371.444 & 6 & 61.907 & & \\
Within groups & 4595.075 & 70 & 65.644 & & \\
Total & 4966.519 & \multicolumn{2}{c}{76} & &
\end{tabular}

When Table 3.b is examined, according to the Anova results, there is a statistically significant difference between the mean scores of state-trait and total anxiety of undergraduate music teacher students by the instruments they play. The mean scores of state-traits and total anxiety levels of undergraduate music teaching students by school years are given in Table 4.

Table 4a. Descriptive Statistics of State-Trait and Total Anxiety Scores by School Years

\begin{tabular}{lccc}
\hline Variables & $\boldsymbol{n}$ & Mean & $\boldsymbol{S D}$ \\
\hline State Anxiety & & & \\
Freshman & 17 & 41.00 & 4.636 \\
Sophomore & 20 & 40.50 & 4.594 \\
Junior & 22 & 41.77 & 7.144 \\
Senior & 18 & 41.72 & 5.706 \\
Total & 77 & 41.25 & 5.611 \\
Trait Anxiety & & & \\
Freshman & 17 & 47.76 & 4.724 \\
Sophomore & 20 & 45.80 & 5.001 \\
Junior & 22 & 45.59 & 5.770 \\
Senior & 18 & 46.88 & 5.860 \\
Total & 77 & 46.42 & 5.346 \\
Total Anxiety & & & \\
Freshman & 17 & 88.76 & 6.638 \\
Sophomore & 20 & 86.30 & 6.408 \\
Junior & 22 & 87.36 & 9.224 \\
Senior & 18 & 88.61 & 9.756 \\
Total & 77 & 87.68 & 8.083 \\
\hline
\end{tabular}


Table 4b. Anova Results of State-Trait and Total Anxiety Scores by School Years

\begin{tabular}{lccccc}
\hline Variables & $\boldsymbol{S S}$ & $\boldsymbol{S d}$ & $\boldsymbol{M S}$ & $\boldsymbol{F}$ & $\boldsymbol{p}$ \\
\hline State Anxiety & & & & & \\
Between groups & 439.683 & 6 & 73.280 & 2.626 & .024 \\
Within groups & 1953.123 & 70 & 27.902 & & \\
Total & 2392.805 & 76 & & & \\
Trait Anxiety & & & & & \\
Between groups & 230.672 & 6 & 38.445 & 1.386 & .233 \\
Within groups & 1942.185 & 70 & 27.745 & & \\
Total & 2172.857 & 76 & & & \\
Total Anxiety & & & & & \\
Between groups & 371.444 & 6 & 61.907 & .943 & .470 \\
Within groups & 4595.075 & 70 & 65.644 & & \\
Total & 4966.519 & 76 & & & \\
\hline
\end{tabular}

According to Table 4.b., there is significant differences between the mean scores of the state-trait and total anxiety levels of undergraduate music teaching students according to the school year variable. The mean scores of state-traits and total anxiety levels of the undergraduate music teacher students by their academic achievement scores are given in Table 5.

Table 5a. Descriptive Statistics of State-Trait and Total Anxiety Scores by Academic Achievements

\begin{tabular}{lrcc}
\hline Variables & $\boldsymbol{n}$ & Mean & SD \\
\hline State Anxiety & & & \\
AA (90-100) & 32 & 43.18 & 6.166 \\
BA (85-89) & 8 & 41.12 & 2.416 \\
BB (75-84) & 16 & 42.37 & 5.018 \\
CB (70-74) & 6 & 34.50 & 4.415 \\
CC (60-69) & 7 & 37.57 & 5.094 \\
DD (45-54) & 2 & 40.00 & 1.414 \\
FD (40-44) & 4 & 39.50 & 1.914 \\
FF (-39) & 2 & 40.00 & 1.414 \\
Total & 77 & 41.25 & 5.611 \\
Trait Anxiety & & & \\
AA (90-100) & 32 & 46.56 & 6.164 \\
BA (85-89) & 8 & 45.37 & 5.153 \\
BB (75-84) & 16 & 46.81 & 4.929 \\
CB (70-74) & 6 & 48.66 & 2.658 \\
CC (60-69) & 7 & 45.28 & 4.386 \\
DD (45-54) & 2 & 45.00 & 1.414 \\
FD (40-44) & 4 & 49.25 & 4.272 \\
FF (-39) & 2 & 38.50 & 4.949 \\
Total & 77 & 46.42 & 5.346 \\
Total Anxiety & & & \\
AA (90-100) & 32 & 89.75 & 9.231 \\
BA (85-89) & 8 & 86.50 & 5.099 \\
BB (75-84) & 16 & 89.18 & 8.565 \\
CB (70-74) & 6 & 83.16 & 5.845 \\
CC (60-69) & 7 & 82.85 & 4.947 \\
DD (45-54) & 2 & 85.00 & 2.828 \\
FD (40-44) & 4 & 88.75 & 2.500 \\
FF (-39) & 2 & 78.50 & 6.363 \\
Toplam & 77 & 87.68 & 8.083 \\
\hline
\end{tabular}


Table 5b. Anova Results of State-Trait and Total Anxiety Scores by Academic Achievement

\begin{tabular}{lccccc}
\hline Variables & \multicolumn{1}{c}{$\boldsymbol{S S}$} & $\boldsymbol{S d}$ & $\boldsymbol{M S}$ & $\boldsymbol{F}$ & $\boldsymbol{p}$ \\
\hline State Anxiety & & & & & \\
Between groups & 439.683 & 6 & 73.280 & 2.626 & .024 \\
Within groups & 1953.123 & 70 & 27.902 & & \\
Total & 2392.805 & 76 & & & \\
Trait Anxiety & & & & & \\
Between groups & 230.672 & 6 & 38.445 & 1.386 & .233 \\
Within groups & 1942.185 & 70 & 27.745 & & \\
Total & 2172.857 & 76 & & & \\
Total Anxiety & & & & & \\
Between groups & 371.444 & 6 & 61.907 & .943 & .470 \\
Within groups & 4595.075 & 70 & 65.644 & & \\
Total & 4966.519 & 76 & & & \\
\hline
\end{tabular}

There is a significant difference between the mean scores of state-traits and total anxiety levels of undergraduate music teaching students in table 5.b.

\section{Conclusions}

According to the results of the study, moving from the performance anxieties of music teaching department undergraduate students at the instrument exams, the following results are obtained in the study: There is a significant difference between the state and trait anxieties of undergraduate music teaching students. It is seen that the trait anxiety experienced by students affect their state anxiety. Individuals with a higher level of anxiety in their daily lives experience state anxiety at a more intense and frequent level than others. When the state-trait and total anxieties of undergraduate music teaching students are examined according to gender, female students have higher trait anxiety than male students on average. Male students' state anxiety, however, was found to be higher than that of females. When it comes to total anxiety, females have higher total anxiety than males. When the state-trait and total anxieties of undergraduate music teaching students are examined according to instruments they play, the trait anxiety level range as viola, violin, baglama, cello=flute, guitar and oud respectively. When it comes to state anxiety level, the range occurs as oud, guitar, baglama, viola, flute, violin and cello respectively. The range is as oud, baglama, viola, guitar, violin, flute and cello respectively in total anxiety levels. When the state-trait and total anxieties of undergraduate music teaching students are examined according to school years, the freshman students are seen to have the highest trait anxiety on average. This is followed by senior, sophomore and junior students respectively. Juniors have the highest state anxiety. They are followed by senior, freshman and sophomore students respectively. When it comes to total anxiety, the most anxious students are the freshman students followed by senior, junior and sophomore students respectively.

When the state-trait and total anxieties of undergraduate music teaching students are examined according to their academic achievement scores, a significant association was found between the academic achievements of the students and their state anxiety levels. Besides, the anxiety levels of students that emerge during the performance has positively and negatively reflected in their grades. Thus, a significant difference was found in state anxiety.

\section{Discussion}

In the study examining the personal features of prospective music teachers and their state anxieties, Topoğlu (2014) found that female students have significantly higher pre-performance anxiety levels than male students. In another study where the state/performance anxiety in music education is compared between the music department and conservatory students, Baydag and Alpagut (2016) found that there is a significant relationship between personality and anxiety and that female students have higher performance anxiety than males. Cirakoglu (2013) Nacakc1 and Dalkiran (2011) also found that performance anxiety may be related to personal characteristics. Iusca and Dafinoiu (2011) examined the effects of gender and instrument on the performance anxiety and performance levels of high 
school students and found that performance anxiety varies by gender and musical instrument. Aydın and İşgörür (2018) addressed music and performance anxieties of conservatory students educated at the secondary and high school level and found that performance anxiety varies by gender. On the other hand, regarding music education, Küçük (2010) found in his study, examining the relationship between exam anxiety, self esteem and instrumental achievement of prospective music teachers, that gender does not have any impact on the exam anxiety of students. Kılıç (2018) also contends based on his study that no significant difference was seen in the anxiety levels of students by gender and age. In another study, Yokuş et al. (2013) found that there is no significant difference in the trait anxieties of prospective music teachers by the gender variable. The results of the foregoing studies are in parallel with the findings of this study. In addition to this, there are also numerous studies supporting these findings in other areas of education. Although the students of bow instruments were expected to have higher anxiety levels, students of string instruments were seen to have higher anxiety levels in our study. Iusca and Dafinoiub (2012) found that among undergraduate students, students of bow instruments have higher anxiety levels than those of piano and wind instruments.

According to the results of this study, the state-trait and total anxiety levels were seen to be higher among the freshman and senior students in terms of school year. It can be thought that the fact that the freshman students are evaluated by the commission for the first time may lead to this outcome. And the senior students can be thought to have anxieties related to their future. However, the anxiety levels of students studying at each undergraduate program play an active role. In his study identifying the differences in the music performance anxiety levels between the younger and older classes in the music teaching undergraduate program, Edmonson (2012) fund that the music performance anxiety may affect the musicians of any professional level. Kılıç (2018) found that the senior students have significantly higher exam performance anxiety levels and are widely concerned about their futures while the freshman students have lower levels of anxiety.

According to the results of this study, it is seen that academic achievement scores is associate with the state-trait and total anxiety levels. It is seen that there is an internal consistency between the performances exhibited by the students and their self evaluations in the scales distributed to them. Besides the commissions in the exams should be careful when grading, and maximum effort should be exerted in order not to reflect the instructor-student relations to the instrument exam grade.

Moving from these results, students should be able to control their anxieties as well as exhibiting their musical and technical skills through their performances in the instrument exams or concerts. Therefore, a musician should attach a great importance to develop a conscious approach to manage his/her performance anxiety, on a par with the importance he/she attaches to his/her technical and musical development from the beginning of the school life. Breathing has an important role in reduction of the students anxiety levels. So technical breath training may take part of the courses in which parallel with the instrument or voice training involving music education program.

\section{References}

Alptekin, A. G. (2012). Müzik performans anksiyetesi. Trakya Üniversitesi Sosyal Bilimler Dergisi, 14(1), 137-148. Retrieved form https://dergipark.org.tr/download/article-file/322027

Aydın, B. \& İşgörür, Ü. (2017). Ortaokul ve lise düzeyinde öğrenim gören konservatuvar öğrencilerinin müzik performans kaygılarının çeşitli değişkenlere göre incelenmesi. Afyon Kocatepe Üniversitesi Akademik Müzik $\begin{array}{lllll}\text { Araştırmalarl Dergisi, } & 4(7), & 1-20 . & \text { Retrieved }\end{array}$ https://amader.aku.edu.tr/wp-content/uploads/2018/02/c4s7_7.-bahar-ayd\%c4\%b1n-\%c3\%bcmit-i\%c5\%9fg\%c 3\%b6r\%c3\%bcr.pdf https://doi.org/10.5578/amrj.66241

Aydın, K. B. (2009). Automatic thoughts as predictors of Turkish university students' state anxiety. Social Behavior and Personality, 37 (8), 1065-1072. https://doi.org/10.5578/amrj.66241

Baydağ, C. \& Alpagut, U. (2016). Müzik eğitimi bölümü ve konservatuvar öğrencilerinin sahne/performans kaygısı açısından karşılaştırılması (pilot çalışma). Uluslararası Sosyal Araştırmalar Dergisi, 9(44), 857-864. https:// doi.org/10.26450/jshsr.600

Cox, W. J. B. \& Kenardy J. (1993). Performance anxiety, social phobia, and setting effects in instrumental music students. Journal of Anxiety Disorders, 7(1), 49-60. https://doi.org/10.1016/0887-6185(93)90020-L

Çırakoğlu, O. C. (2013). Sahnedeki düşman: müzisyenlerde performans kaygısı üzerine bir gözden geçirme. Türk Psikoloji Yazllarl, 16(32), 95-104. Retrieved from https://www.researchgate.net/publication/317957144 
Çimen, G. (2001). Konser Kaygısı. G.Ü. Gazi Eğitim Fakültesi Dergisi, 21(2), 125-133. Retrieved from http://gefad.gazi.edu.tr/article/view/5000078954

Dalkıran, E. (2015). Kendini değerlendirme ve sınav performansı arasındaki ilişki ile sınav kaygısının sınav performansinı yordama etkisinin incelenmesi. International Journal of Social Sciences and Education Research, 1(4), 1132-1141. https://doi.org/10.24289/ijsser.279123

Dalkıran, E., Şahin Baltacı, H., Karataş, Z. \& Nacakcı, Z. (2014). Bireysel çalgı performans sınavı kaygı ölçeğinin geliştirilmesi: geçerlik-güvenirlik çalışması. International Journal of Assessment Tools in Education, 1(1), 13-25. https://doi.org/10.21449/ijate.239569

Edmonson, J. M. (2012). Differences in music performance anxiety levels between underclassmen and upperclassmen music education undergraduates. Texas Music Education Research, 15-19. Retrieved from https://archive.org/details/ERIC_EJ1102261

Fehm, L. \& Schmidt, K. (2006). Performance anxiety in gifted adolescent musicians. Journal of Anxiety Disorders, 20, 98-109. Retrieved from https://doi.org/10.1016/j.janxdis.2004.11.011

Işkın, S. (2018). Mesleki müzik eğitimi veren kurumlarda performans kaygısı ve öz-yeterlik algısının çalgı başarısına etkisi. Marmara University Institute of Educational Sciences Department of Fine Arts Education Master's Thesis, İstanbul.

Lusca, D. \& Dafinoiu, I. (2011). Performance anxiety and musical level of undergraduatestudents in exam situations: the role of gender and musical instrument. Procedia - Social and Behavioral Sciences, 33, 448-452. https://doi.org/10.1016/j.sbspro.2012.01.161

Karagüvan, M. H. Ü. (1999). Açık kaygı ölçeğinin geçerlik ve güvenirliği ile ilgili bir çalışma. M.Ü. Atatürk Eğitim Fakültesi Eğitim Bilimleri Dergisi, 11, 203-218. Retrieved from http://hdl.handle.net/11424/3392

Karasar, N. (2005). Bilimsel Araştırma Yöntemi. Ankara: Nobel Publication Distribution

Kenny, D. T., Davis, P. \& Oates, J. (2004). Music performance anxiety and occupational stres amongst opera chorus artists and their relationship with state and trait anxiety and perfectionism. Journal of Anxiety Disorders, 18, 757-777. https://doi.org/10.1016/j.janxdis.2003.09.004

Kenny, D. T. \& Osborne, M. S. (2006). "Music performance anxiety: new insights from young musicians. Advances in Cognitive Psychology, 2(3), 103-112. http://dx.doi.org/10.2478/v10053-008-0049-5

K1lıç, D. B. Ç. (2018). An investigation of music teacher candidates' performance anxiety levels in piano examinations. Journal of Education and Learning, 7(1). 299-308. https://doi.org/10.5539/jel.v7n1p299

Küçük, D. P. (2010). Müzik öğretmeni adaylarının sınav kaygısı, benlik saygısı ve çalgı başarıları arasındaki ilişkinin incelenmesi. Ahi Evran Üniversitesi Ĕ̆itim Fakültesi Dergisi, 11(3), 37-50. Retrieved from http://kefad.ahievran.edu.tr/InstitutionArchiveFiles/f44778c7ad4ae71180ef00224d68272d/d1a3a581af4ae71180 ef00224d68272d/Cilt11Sayi3/JKEF_11_3_2010_37_50.pdf

Lau, J. Y. F., Eley, T. C. \& Stevenson, J. (2006). Examining the state-trait anxiety relationship: a behavioural genetic approach. Journal of Abnormal Child Psychology, 34(1), 19-27. https://doi.org/10.1007/s10802-005-9006-7

Nacakcı, Z. \& Dalkıran, E. (2011). Müzik eğitimi anabilim dalı öğrencilerinin bireysel çalgı sınavına yönelik kaygıları. Mehmet Akif Ersoy Üniversitesi Sosyal Bilimler Enstitüsü Dergisi, 3(5), 46-56. Retrieved from http://dergipark.org.tr/makusobed/issue/19437/206721

Osborne, M. S., Greene, D. J. \& Immel, D. T. (2014). Managing performance anxiety and improving mental skills in conservatoire students through performance psychology training: a pilot study. Osborne et al. Psychology of Well-Being: Theory, Research and Practice, 4(18), 2-17. https://doi.org/10.1186/s13612-014-0018-3

Öner, N. \& LeCompte, A. (1985). Durumluk-sürekli kaygı envanteri el kitabı. İstanbul, Boğaziçi Üniversitesi Yayınları.

Umuzdaş, M. S. (2010). Gazi eğitim fakültesi müzik öğretmenliği programı piyano öğrencilerinin kaygı düzeylerinin incelenmesi. Kastamonu Ë̆itim Dergisi, 18(3), 943-960. Retrieved from http://www.kefdergi.com/pdf/18_3/18_3_19.pdf

Papageorgi, I., Hallam, S. \& Welch, G. F. (2007). A conceptual framework for understanding musical performance anxiety. Research Studies in Music 83-107. https://doi.org/10.1177/1321103X070280010207 
Sadler, M. \& Miller, C. J. (2010). Performance Anxiety: A Longitudinal Study of the Roles of Personality and Experience in Musicians. Social Psychological and Personality Science, 1(3) 280-287. https://doi.org/10.1177/1948550610370492

Sarıkaya, M. \& Kurtarslan, Z. (2018). Prediction of musical performance anxiety according to music teacher candidates' perfectionism and self-efficacy beliefs. International Online Journal of Educational Sciences, 10(4), 183-198. https://doi.org/10.15345/iojes.2018.04.010

Topcan, T. (2018). Sahnede müzik performansı sergileyen öğrencilerin kaygı durumunu etkileyen faktörlerin önem sıralamas1: ankara ili örneği. Social Sciences Studies Journal, 4(19), 2010-2019. Retrieved from http://sssjournal.com/DergiTamDetay.aspx?ID=594 https://doi.org/10.26449/sssj.594

Topoğlu, O. (2014). Musical performance anxiety: relations between personal features and state anxiety levels of pre-service music teachers. International Online Journal of Educational Sciences, 6(2), 337-348. https://doi.org/10.15345/iojes.2014.02.008

Topoğlu, O. (2013). Müzisyenlerde sahne korkusu, sahne korkusunun nedenleri ve sahne korkusuyla baş etmede kullanilabilecek stratejiler. E-Journal of New World Sciences Academy, 8(1), 43-55. Retrieved from https://dergipark.org.tr/download/article-file/186507

Yokuş, T., Yokuş, H. \& Kalaycıoğlu, Ş.G. (2013). Müzik öğretmeni aday adaylarının sürekli-durumluk kaygı düzeyleri ve müzik özel yetenek sınavı başarıları arasındaki ilişkinin incelenmesi. E- Journal of New World Sciences Academy, 8(1), 153-163. Retrieved from https://dergipark.org.tr/nwsafine/issue/19893/213049

Yoshie, M., Shigemasy, K., Kudo, K. \& Ohtsuki, T. (2009). Effects of state anxiety on music performance: Relationship between the Revised Competitive State Anxiety inventory-2 subscales and piano performance. Social Psychological and Personality Science, l(3), 280-287. https://doi.org/10.1177/1029864909013001003

Yöndem, Z. D. (2012). Müzik öğrencilerinde algılanan performans kaygısının fiziksel, davranışsal ve bilişsel özellikleri: nitel bir çalışma. Eğitim ve Bilim Dergisi, 37(116), 182-194. Retrieved from http://egitimvebilim.ted.org.tr/index.php/EB/article/view/1427 